\title{
Changing streamflow on Columbia basin tribal lands-climate change and salmon
}

\author{
Kyle Dittmer
}

Received: 12 November 2012 / Accepted: 17 February 2013 / Published online: 17 April 2013

C The Author(s) 2013. This article is published with open access at Springerlink.com

\begin{abstract}
Over the last 100 years, linear trends of tributary streamflow have changed on Columbia River Basin tribal reservations and historical lands ceded by tribes in treaties with the United States. Analysis of independent flow measures (Seasonal Flow Fraction, Center Timing, Spring Flow Onset, High Flow, Low Flow) using the Student $t$ test and MannKendall trend test suggests evidence for climate change trends for many of the 32 study basins. The trends exist despite interannual climate variability driven by the El NiñoSouthern Oscillation and Pacific Decadal Oscillation. The average April—July flow volume declined by $16 \%$. The median runoff volume date has moved earlier by 5.8 days. The Spring Flow Onset date has shifted earlier by 5.7 days. The trend of the flow standard deviation (i.e., weather variability) increased $3 \%$ to $11 \%$. The 100 -year November floods increased $49 \%$. The mid-Columbia 7Q10 low flows have decreased by $5 \%$ to $38 \%$. Continuation of these climatic and hydrological trends may seriously challenge the future of salmon, their critical habitats, and the tribal peoples who depend upon these resources for their traditional livelihood, subsistence, and ceremonial purposes.
\end{abstract}

\section{Introduction}

For 36 years, the Columbia River Inter-Tribal Fish Commission (CRITFC), along with its member tribes, the Nez Perce Tribe, the Confederated Tribes of the Umatilla Indian Reservation, the Yakama Nation, and the Confederated Tribes of Warm Springs Reservation of Oregon (Fig. 1), have worked to halt and reverse the decline of Pacific Northwest salmon, steelhead, Pacific lamprey, and sturgeon populations. These fish are of great cultural, subsistence, and commercial value to CRITFC's member tribes. Salmon are

This article is part of a Special Issue on "Climate Change and Indigenous Peoples in the United States: Impacts, Experiences, and Actions” edited by Julie Koppel Maldonado, Rajul E. Pandya, and Benedict J. Colombi.

Electronic supplementary material The online version of this article (doi:10.1007/s10584-013-0745-0) contains supplementary material, which is available to authorized users.

K. Dittmer $(\bowtie)$

Columbia River Inter-Tribal Fish Commission, 729 NE Oregon Street - Suite 200, Portland,

OR 97232-2107, USA

e-mail:ditk@critfc.org 


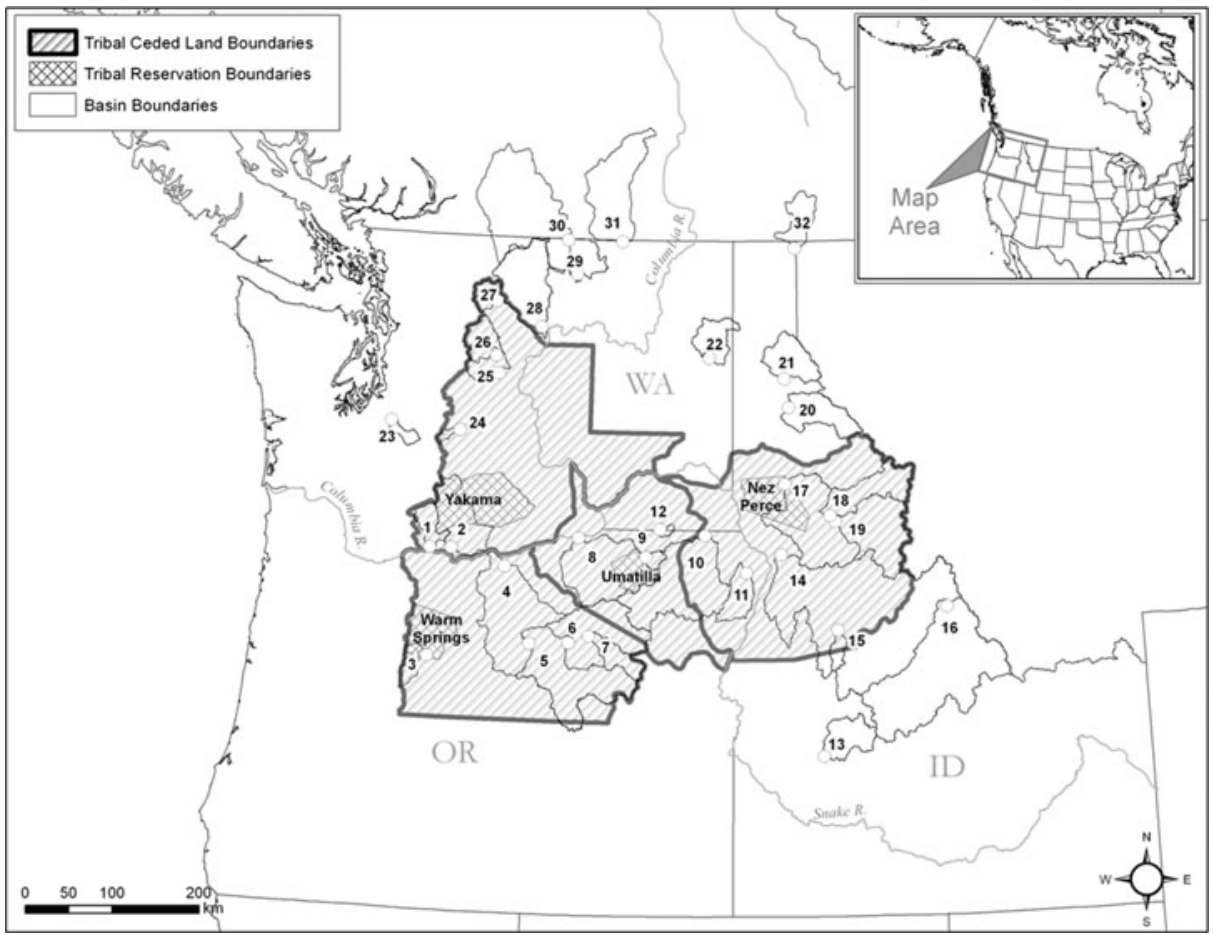

Fig. 1 Columbia River Treaty-Tribal lands and ceded areas (refer to Online Resource 1 for stations)

more than just a major food source - they are an important part of tribal longhouse religious services (e.g., First Salmon ceremony), cultural identity, sense of traditional place, traditional nutritional health, transferal of traditional values to the next generation, and livelihood (CRITFC 2013a). Salmon are the first in a line of sacred foods (Drummond and Steele 2013) — elk, deer, roots, and berries - that have been in decline due to degraded ecosystems (which are likely to be more vulnerable to future climate change impacts). CRITFC is a technical service agency for its member tribes, who, due to federal court interpretations of treaties with the United States (Weaver 1997), are co-managers of the fishery resource, along with the states of Oregon, Washington, and Idaho as well as NOAA-Fisheries and U.S Fish and Wildlife Service. CRITFC produced a comprehensive basin-wide salmon restoration plan, called Wy-Kan-Ush-Mi Wa-Kish-Wit or "Spirit of the Salmon" (CRITFC 1995), which includes recommendations for river flows, hydropower operations, and temperature regimes to increase fishery productivity. The plan is being updated, which will include strategies to mitigate for climate change, and will be available by July 2013 .

CRITFC and its member tribes are concerned about climate change impacts to treatyprotected tribal fishery, water, and food resources. Climate change impacts could negatively affect critical life history stages for salmon and their habitat (ISAB 2007; Mantua et al. 2008; Crozier et al. 2008).

This study offers a retrospective analysis of changes in tributary streamflow that occurred during 1904-1930 to 2009 for the Columbia Basin tribal lands and ceded areas (i.e., territory ceded to the United States by the tribes in the Treaties of 1855 in exchange for the right to fish, hunt, and gather native plants on ancestral lands). This study serves as an important 
hydrological baseline for anadromous fish (e.g., salmon, Pacific lamprey, etc.) habitat and productivity that may be altered by climate change as a future limiting factor.

Salmon spend 50-90\% of their lives in the ocean (Quinn 2005). Their initial life cycle in the rivers and lakes is crucial for their survival chances in the estuary and coastal ocean. Salmon start as eggs laid down in river gravels during August-October (Fig. 2). The length of development depends on the Temperature Unit, the seasonal accumulation of heat energy. By spring, when the TU reaches 500, salmon fry hatch in the gravels where they stay and grow. By late spring and summer, when the TU reaches 1000, they are large enough as smolts to migrate downriver. The migration season is April through September (Fig. 3). Long-term changes to their freshwater habitats will likely impact their long-term survival and recovery prospects. For example, warming water temperatures can cause early emergence for fry (see Fig. 11, Mantua et al. 2008). Quinn (2005) noted that salmon have been highly challenged by human activities for over 100 years: "Given the high fishing rates, habitat loss and degradation, careless transfers of fish among basins, overzealous hatchery propagation, and other stressors, the remarkable thing is not that salmon are in danger but that they still persist at all...."

Pacific lampreys, a critical tribal cultural food resource, spend $60-70 \%$ of their life-cycle in freshwater (Quinn 2005). Lampreys are often associated with Pacific Salmon as an indicator species and an important ecological component of freshwater streams providing marine-derived nutrients. The development of hydropower, degradation of habitat, and passage barriers have likely contributed in a decline from almost 380,000 adults counted at Bonneville Dam in 1969 to less than 30,000 in recent years (Luzier et al. 2011). The

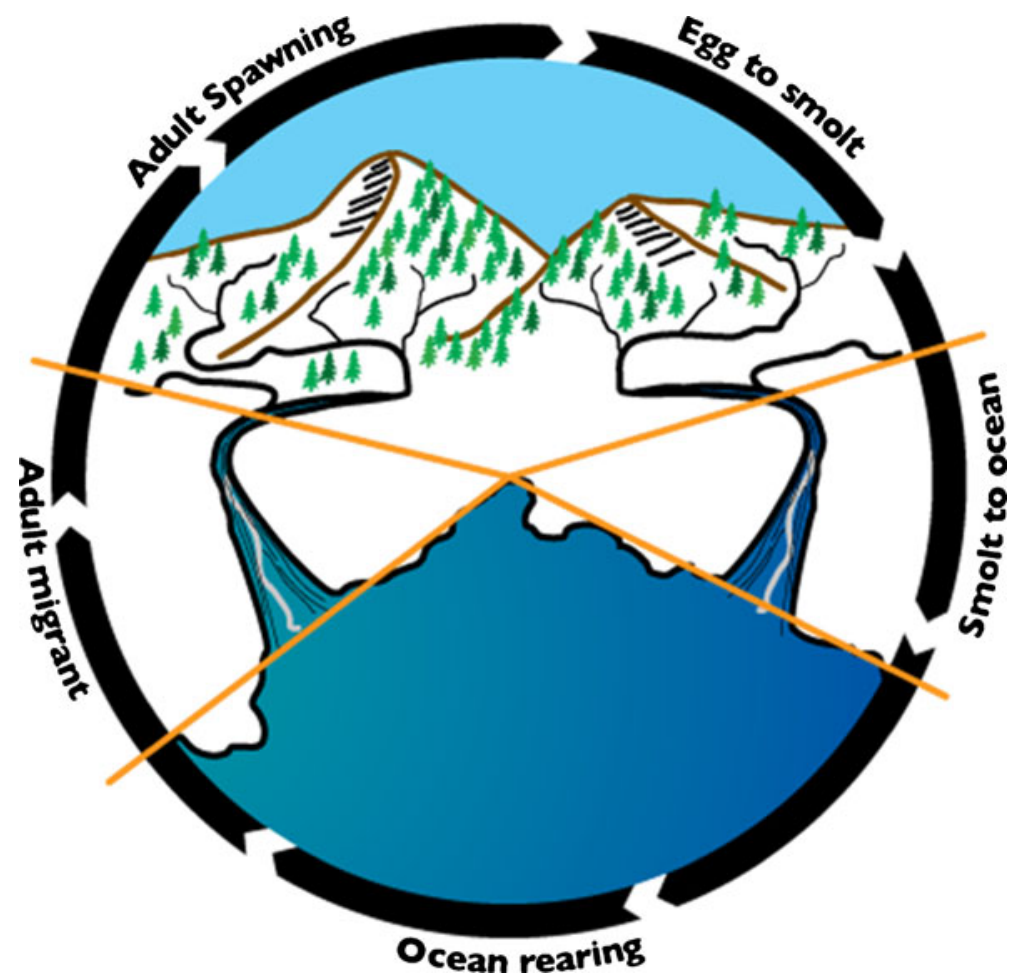

Fig. 2 Salmon Life Cycle (CRITFC 2013b) 


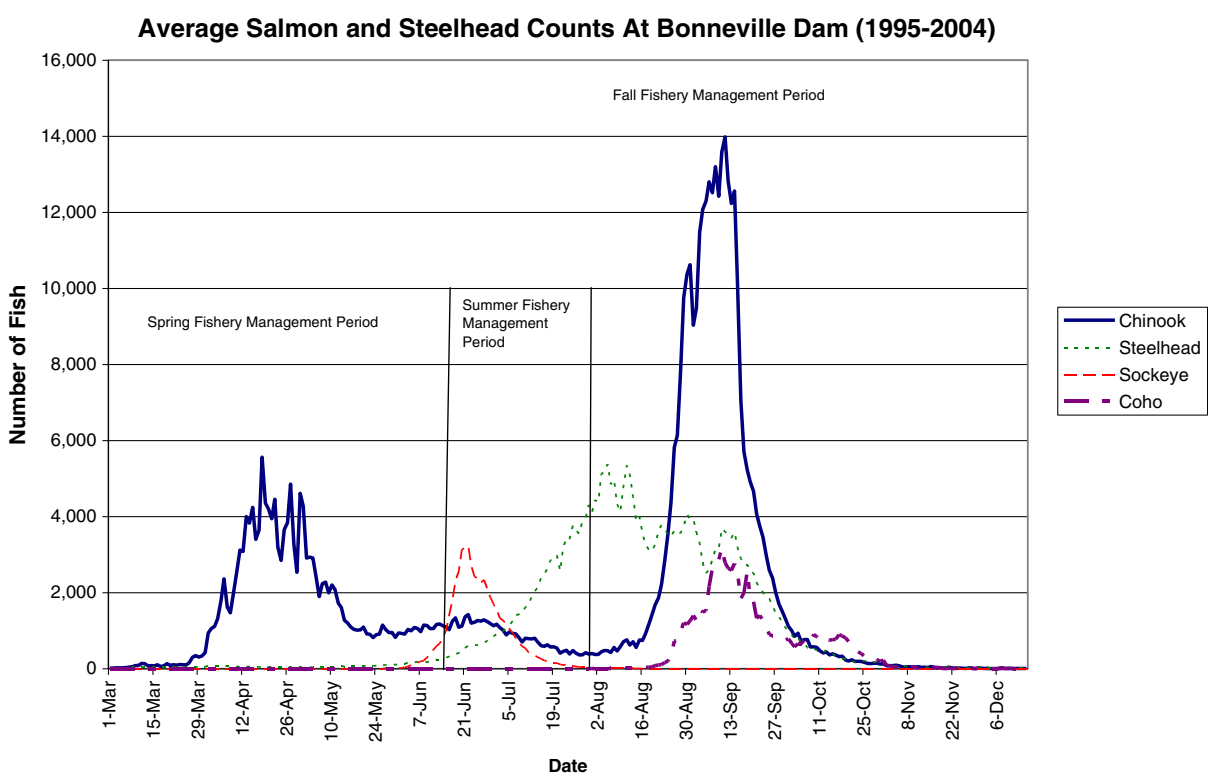

Fig. 3 Seasonal adult salmon abundance and run timing for the Columbia basin, which shows how biological timing intersects with changing streamflow (FPC 2012)

Columbia Basin tribes have developed a Lamprey Restoration Plan (CRITFC 2013c) to address these issues with the goal to restore lamprey throughout their entire range.

Changing tributary streamflow fueled by future climate change will be layered upon a Columbia-Snake River Basin (NPCC 2007) which is the most developed and regulated hydropower system in the world (Cohen et al. 2000). Anadromous fish must migrate through 1-9 major run-of-river projects on the Columbia and Snake Rivers (Fig. 4) twice in order to reach their spawning grounds in the tributary basins, once as juveniles heading to the ocean and later as adults migrating upstream to their spawning grounds. The development of 30 major dams for the Columbia River Basin Federal hydro-system, from 1938 (Bonneville Dam) to 1983 (Revelstoke Dam, BC), was for flood control, hydropower, then later on irrigation, navigation, and recreation. While upstream fish passage was originally accommodated at many dams, until recently, downstream passage and protection measures of critical habitat were not.

\section{Methods}

\subsection{Temperature and precipitation data}

Monthly values of the Geographic Information System-based PRISM or Parameterevaluation Regressions on Independent Slopes Model (Daly et al. 1994; PRISM 2012) for 1900-2009 were processed for most basins in this study. The 800-m cell-resolution climate data were intersected by study basin delineations. Mean climate data were then computed for each study basin, except for those basins in Canada, as PRISM data doesn't extend into Canada. The PRISM method is ideally suited for complex mountainous terrain (PRISM 2012). Annual maximum and minimum air temperatures plus precipitation data were averaged as three-year moving averages for each basin to enhance the signal-to-noise pattern. 


\section{Map of the Columbia River Basin}

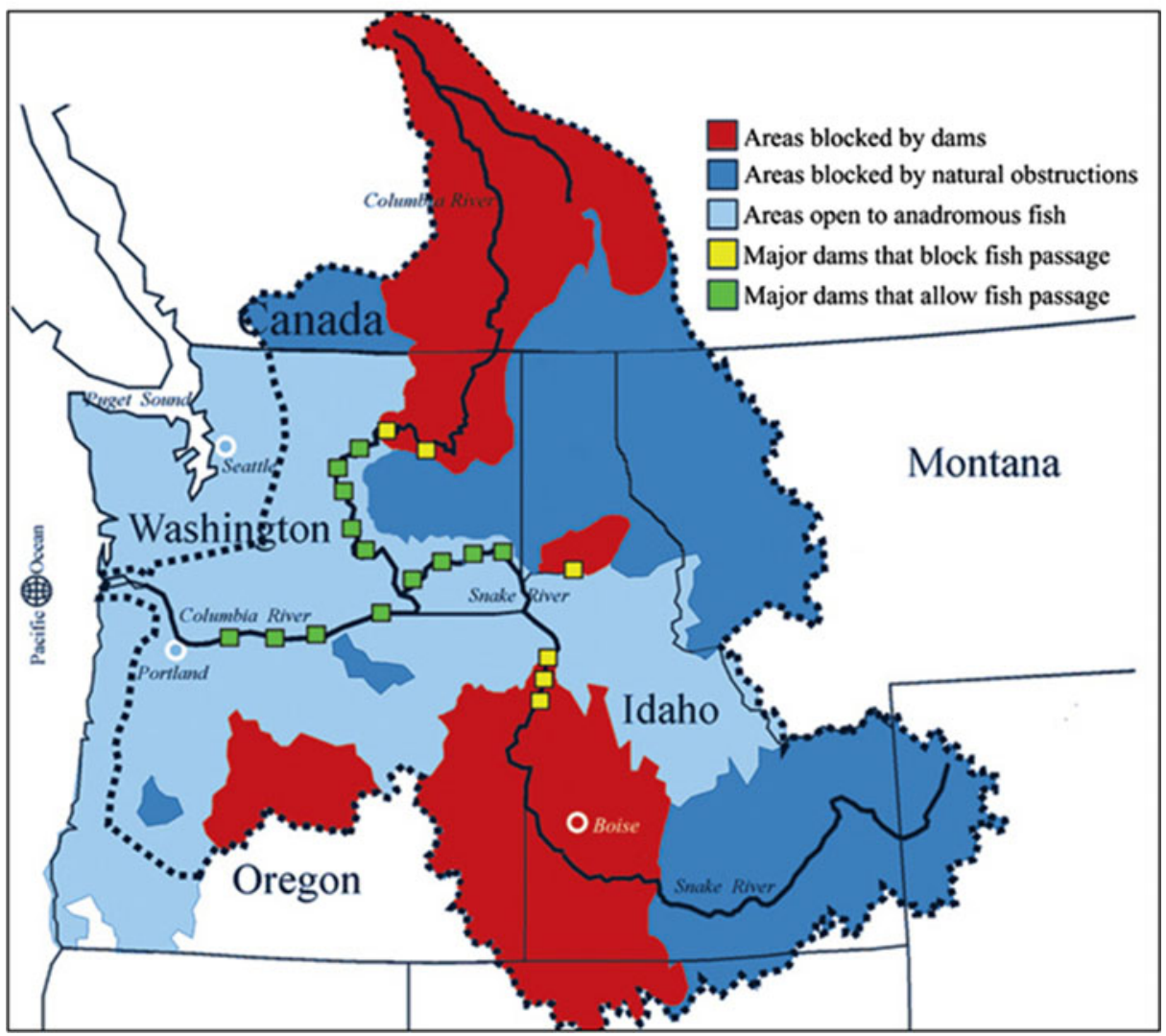

Fig. 4 Columbia River Basin (dotted line) and its salmon (i.e., anadromous fish) passage aspects (NPCC 2013)

\subsection{Flow data}

The flow data series were downloaded for U.S. Geological Survey (USGS) stream gages (USGS 2012) and imported into EXCEL spreadsheets. Many gages are part of the USGS Hydro-Climate Data Network or HCDN (Slack and Landwehr 1992). The HCDN gages are deemed desirable for climate change studies because they represent basins with few or no anthropogenic effects and are best suited for climate change studies.

The observed flow data for 21 of 32 basins in this study were "naturalized" by removing historical irrigation diversion (i.e., gravity and sprinkler systems) and return-flow depletion data compiled by the Federal power-marketing agency, BPA (BPA 2011). BPA obtained irrigation withdrawal monthly flow data from water reports from the USDA's National Agricultural Statistics Service (USDA-NASS 1997), USGS National Water-Use Program (USGS 1995), and the British Columbia Census on Agriculture. The BPA analysis also took into account the changing (usually increasing) irrigation withdrawals over time. In EXCEL, the modifiedadjusted flow dataset is the observed flow series minus the irrigation depletion data (negative values) for each day of each month throughout the station record. An example is the Methow River at Pateros, for May 1, 2000: $2961 \mathrm{cfs}$ (natural)=2860 (observed)-[-101 (irrigation)]. 


\subsection{Tributary basins}

Thirty-two snowmelt-dominant basins located on or near tribal ceded lands, were selected (Fig. 1, Online Resource 1) with the criteria: (1) at least 65 years of streamflow record, (2) no more than $20 \%$ record gaps, (3) unregulated streams, (4) avoid very low flow records with inconsistent trends (i.e., poor signal-to noise patterns) relative to adjacent basins. Some station records with gaps were filled in by daily synthetic flows derived by the author based on significant $(\mathrm{R} 2=0.5-0.9)$ multi-month regressions with one or two adjacent basin daily gage records. Due to the significant influence of water resource projects and other anthropogenic changes, other gage records deemed desirable were rejected from this study.

The study basins are located in warm-summer continental climates (see Fig. 4 in Elsner et al. 2009). The majority of precipitation falls in autumn-winter followed by dry summers. The peak runoff occurs in May-June. The lowest flow occurs in August through October. Columbia Basin snowfall occurs November through March; snowmelt is during April through July (Mote and Salathé 2010).

\subsection{Flow measures}

This study considers independent ways to measure changes in streamflow and includes:

(1) Seasonal Flow Fraction (SFF). The SFF is defined as a ratio of the spring-summer streamflow volume to the water year streamflow volume (Stewart et al. 2005). Aguado et al. (1992) plus Dettinger and Cayan (1995) performed similar analysis for the basins of the Sierra Nevada Mountains. Dettinger and Cayan (1995) also noted that the hydroclimate of the Pacific Northwest varied more considerably than California. The springsummer period is important to the life cycle of salmon (ISG 2000), as water is needed for juvenile and adult salmon habitat and migration, and so will be emphasized. For this work, the spring-summer streamflow is defined as flow rate during April through July, which corresponds to the same period in Stewart et al. (2005) for basins across the western U.S.

(2) Center (of volume) Timing (CT). The CT is the Julian-day of the median of the daily streamflow accumulation through the water year (Stewart et al. 2005). The CT is preferable to the observed daily peak flow, because unusual weather events (e.g., rainon-snow) can obscure an annual peak flow (Hidalgo et al. 2009; Maurer et al. 2007). The CT is a close proxy to the annual peak flow and allows for more consistent, robust results.

(3) Spring Flow Onset (SFO). The SFO is the start-date of the annual snow-melt. Cayan et al. (2001) defined the start-date of the SFO when the cumulative total of daily flow departures from the mean streamflow are at a minimum. This is equivalent to the date when streamflow shifts to a rapid rise due to snow-melt. This study uses the period January 1 to July 31 to compute the mean, as most of the annual snow-melt in the Pacific Northwest is complete by July. Stewart et al. (2005) used January 9 to September 5. Cayan et al. (2001) used January 9 to July 27. Those studies examined stream gages across the western U.S., which encompasses more varied terrain than is considered in this study of the rivers of the Columbia Basin.

(4) High Flow (HF). The HF is defined as the largest daily streamflow that occurs during one autumn month. October, November, and December were chosen, given the seasonal increase in Pacific Coast storms and high flow timing shifts across the western U.S. (Hamlet and Lettenmaier 2007), the vulnerable time for salmon egg nests (ISAB 2007), and the linkage between egg mortality and high flow scour events (Jager et al. 
1997). A frequency analysis was plotted for each basin. The 10-year and 100-year flows were computed from these data using the log-Pearson Type III and Gumbel distributions (Linsley et al. 1982).

(5) Low Flow (LF). The LF is defined as the 7Q10 flow (i.e., lowest streamflow over seven consecutive days having a 10-year recurrence interval) during August 1 to November 15, when most anadromous fish are likely to spawn and need critical habitat, e.g., flows of adequate quantity and quality with cool temperatures. Jager et al. (1997) state that salmon egg mortality risk is caused by extreme temperatures, loss of habitat due to extreme high and low flow events, and superimposition of eggs. A frequency analysis was plotted for each basin. The 7Q10 was computed using the logPearson Type III and Gumbel distributions (Linsley et al. 1982).

\subsection{Trend analysis and hydroclimatology}

Linear trends of the five streamflow metrics were computed for annual, three-year and five-year moving average time steps. Each trend was compared during the following time periods: 19622009 vs. $1900-61,1977-2009$ vs. $1925-56,1947-76$ vs. 1900-24, 1999-2009 vs. 1900-24, and $1977-98$ vs. 1925-46. Each time period represents a part of the Pacific Ocean climate variability, as measured by El Niño-Southern Oscillation (ENSO) and the Pacific Decadal Oscillation (PDO). Both strongly control Columbia Basin hydrometeorology and its influence on Columbia Basin runoff (Miles et al. 2000; Mote and Salathé 2010). Time periods are based on natural breaks of the PDO, which Mantua et al. (1997) identified as 1900-24 (cold phase), 1925-46 (warm phase), 1947-76 (cold phase), and 1977-98 (warm phase), and chosen to minimize the climate variability influence of the PDO.

The two-tailed Student $t$ test (i.e., comparing the means and distributions of two populations) and the Mann-Kendall trend test were computed for each flow measure for each basin. The Mann-Kendall test (Helsel and Hirsch 1992) is a non-parametric statistic that detects a trend in time-series data, which can be very scattered. These tests are commonly used in water resources analyses (Helsel and Hirsch 1992). Onoz and Bayazit (2003) showed that the $t$ test and MannKendall test are good tests for trend detection using streamflow data from Turkey.

\section{Results}

\subsection{Temperature and precipitation data}

The PRISM data (Online Resource 2) show a mean change of $+0.6^{\circ} \mathrm{C}$ (range -0.2 to 1.7 ) and $+1.6^{\circ} \mathrm{C}$ (range 0.4 to 2.4 ) per century, for the maximum and minimum air temperatures, respectively, and $+46 \mathrm{~mm}$ (range -14 to +210 ) per century for precipitation. The MannKendall results show significance $(p \leq 0.05$ level) in trends for 18 basins of maximum air temperature, 32 basins for minimum air temperature, and four basins for precipitation. The R2 values of $0.1-0.75$ are driven by variable interannual weather patterns of the Pacific Northwest (Hamlet et al. 2005).

\subsection{Seasonal flow fraction}

The 3-year moving average SFF (Online Resource 3), on average, declined $16 \%$ per century for spring-summer flows (range of $-35 \%$ to $-2 \%$ ). Of the 32 basins none experienced an increase in SFF for spring-summer flows, nine basins had a 2-10\% decline, eleven had an 
11-20\% decline, ten had a $21-30 \%$ decline, and two had a $32-35 \%$ decline. A multi-year moving average can enhance the signal-to-noise aspect and statistical robustness of the annual data. The 3-year moving average gave the best results (vs. annual or 5-year steps). The 3-year SFF average is $1 \%$ higher than the annual data. Plots of annual data (Online Resource 3) do show the temporal changes and trend of variability. The basins of northeast Oregon, using non-HCDN data, compare very well with adjacent basins that use HCDN data.

The $t$ test shows the significance $(p \leq 0.05)$ in the SFF flows for the Late Century (19622009) versus the Early Century (1900-61) period (i.e., "LC vs. EC"), representing a mixed PDO phase (i.e., part warm, part cold phase) of two lengthy time periods (3-year moving average data) for 16 basins (Online Resource 4). A hybrid period (i.e., start of a warm phase PDO continuing through part of a cold phase), 1977-2009 (representing modern conditions) vs. 1925-57 (i.e., "W-C" or warm-cold phase), has significance for 17 basins. Other time spans of PDO phases were not as robust. The average standard deviation (Online Resource 4) increased $5 \%$ (range $-18 \%$ to $+57 \%$ ) with 15 basins showing a positive trend and implies that hydrometeorological variability is increasing. The Mann-Kendall results show significance $(p \leq 0.05)$ for a trend for ten (SFF), two (CT), and four (SFO) basins.

\subsection{Center timing}

The 3-year moving average CT seasonal date (Online Resource 5) has decreased (i.e., shifted earlier) on average by 5.8 days (range -17.2 to +2.3 days). The 3 -year CT average is +0.6 day higher than the annual data. Plots of annual data are shown in Online Resource 5. The $t$ test shows the significance $(p \leq 0.05)$ in the mean flows (3-year moving average data) for the "LC vs. EC" period and hybrid warm-cold ("W-C") phase PDO for six basins. The average standard deviation increased $3 \%$ (range $-16 \%$ to $+89 \%$ ) with 12 basins showing a positive trend (Online Resource 4) and suggests that hydrometeorological variability is increasing. There is a preponderance of smaller shifts in CT for the higher elevation basins above 1,200 m (Online Resource 5) but the scatter of the data makes more refined interpretation difficult.

\subsection{Spring flow onset}

The 3-year moving average SFO seasonal date (Online Resource 6) has shifted earlier on average by 5.7 days (range to -32.7 to +11 days). The 3 -year SFO average is +0.8 day higher than the annual data. Plots of annual data are shown in Online Resource 6. The $t$ test shows the significance $(p \leq 0.05)$ in the mean flows (3-year average data) for the "LC vs. EC" period for five basins. The hybrid warm-cold phase PDO has significance for six basins. The average standard deviation increased $11 \%$ (range $-24 \%$ to $+57 \%$ ) with 21 basins showing a positive trend (Online Resource 4), which implies hydrometeorological variability is increasing. The SFO and CT data are significantly correlated for $44 \%$ (annual) and $58 \%$ (3-year average) of the gages. Stewart et al. (2005) found a $74 \%$ correlation for SFO and CT.

\subsection{High flows}

Online Resource 7 shows for the "LC vs. EC" period the average 100-year flood decreased $7 \%$ (range $-72 \%$ to $+113 \%$ ) in October, increased $49 \%$ (range $-24 \%$ to $+150 \%$ ) in November, and increased $4 \%$ (range $-38 \%$ to $+38 \%$ ) in December. The $t$ test shows the significance $(p \leq 0.05)$ in the flows for the "LC vs. EC" period for three basins (October) and 
one basin (November). Given the highly complex pattern of change across basin geography, elevation, location, and autumn month, a break-out of these months (Online Resource 7) gives more statistical robustness rather than looking at a bulk seasonal value. Plots of annual data (Online Resource 7) show the likelihood for higher flow has increased since 1961. The average standard deviation (Online Resource 4) decreased $5 \%$ in October (range $-76 \%$ to $+142 \%$ ), increased $61 \%$ in November (range $-5 \%$ to $+194 \%$ ), and increased $21 \%$ in December (range $-29 \%$ to $+176 \%$ ), which suggests that the variability in mid-autumn rainfall-driven flood events is increasing. Hamlet and Lettenmaier (2007) have studied the change in flood risk in the western U.S. for snow and rain-dominated basins and detected an increasing flood risk in basins with a transient (i.e., mixed snow/rain) hydrology.

The HF results are consistent with Dettinger (2011) which describes Atmospheric River (AR) events, a.k.a. "Pineapple Express" storms (i.e., intense warm, moist jet-streams from near Hawaii) striking California and the impact of climate change. He noted an increase of AR events and flooding in the last 50 years and to expect an increase in future frequency and magnitude ( +0.3 to +7.2 AR days per century).

\subsection{Low flows}

Online Resource 8 shows that for the "LC vs. EC" period the average 7Q10 increased $4 \%$ (range $-38 \%$ to $+38 \%$ ). The average standard deviation (Online Resource 4 ) increased $1 \%$ (range $-65 \%$ to $+71 \%$ ) with 16 basins showing a positive trend. The $t$ test shows significance $(p \leq 0.05)$ for six basins. The Mann-Kendall results show significance $(p \leq 0.05)$ for a trend for seven basins. An increase in frequency of low flows exists for the basins of northeast Oregon and central Idaho and a $5 \%$ to $38 \%$ decrease (i.e., drying trend) of the east-slope Washington Cascades and north Idaho. Time series plots (Online Resource 8) show the trend for select east-slope Washington Cascades basins.

\subsection{Basin elevation analysis}

GIS was used to delineate basins into areas (Online Resource 9) above and below 1,200 m, the modern mean midwinter snow-lines for the Cascade Mountains (Meyer and Dodge 1988), and 1,800 m, which Mote (2003) identified as an elevation above which there is little change in the trend of the historical April $1^{\text {st }}$ snow water equivalents for the Cascades. Local NWS meteorologists report that midwinter snowlines hover at $1,200 \mathrm{~m}$ for basins west of the Cascades and 300-600 m east of the Cascades.

For land below these two elevation criteria, the effects of long-term trends are great, as seen in the CT data (Online Resource 5). The mean basin area below 1,200 $\mathrm{m}$ is $41 \%$ (range $0 \%$ to $98 \%$ ) and below $1,800 \mathrm{~m}$ the mean is $80 \%$ (range $7 \%$ to $100 \%$ ). The greatest streamflow change occurs in the low elevation transition-type basins of northeast Oregon (which is near the main salmon migration corridor) and north-central Idaho.

\section{Discussion}

\subsection{Trends in streamflow timing}

For their 302 stations across western U.S., Stewart et al. (2005) saw 0-20\% declines in the SFF for the Pacific Northwest stations for their 1948-2002 record. This shift compares well 
with the 2-35\% declines in this study. For the CT metric, Stewart et al. (2005) found that 10-30 day earlier shifts were clustered in the Pacific Northwest, Sierra Nevada, coastal Canada, and Alaska and compares well with the +2 to -17 day shifts in this study. For the SFO metric, Stewart et al. (2005) saw 10-30 day earlier shifts in timing using the SFO metric and compares well with the +11 to -32 day shifts in this study.

These shifts are likely driven by changes in warming winter temperatures, which affects the Snow Water Equivalent (SWE) of snowpacks (Mote et al. 2008). Plots (Online Resource 10) of peak April $1^{\text {st }}$ SWE versus the November-March precipitation of SNOTEL/snow courses (Barnett et al. 2005) in/near the study basins show the trend of SWE as $-0.2 \%$ to $-0.9 \%$ per year, as a fraction of total winter precipitation. This finding is supported by Pelto's (2008) $-0.4 \%$ to $-1.1 \%$ per year (1946-1005) decline in the April $1^{\text {st }} \mathrm{SWE}$ for five SNOTEL sites in the North Cascades of Washington.

\subsection{Pacific Ocean and Pacific Northwest hydroclimatology}

The interannual variability of Pacific Northwest weather patterns caused by the positive and negative annual phases of ENSO, combined with the 20-30 year phases of PDO (Fig. 3 from CIG 2012), is a confounding reality when trying to interpret streamflow trends. Other workers have also noted this obstacle. Beebee and Manga (2004) warn that the starting point of a trend analysis, which depends on a PDO phase, determines the type of trend, if any. They used USGS records before 1940 for small unregulated and undeveloped basins in Oregon to increase the ratio of snowmelt signal to Southern Oscillation Index and PDO indices. Their results suggest that the strength of the correlation depends on the PDO phase, but the correlation coefficients are only $0.10-0.57$. It may not be possible to delineate a strong trend of climate elements, given such interannual variability, with 100 years of data.

\subsection{Fishery restoration}

The change in streamflow timing and volume will have differing impacts on Columbia Basin salmon, depending on the species, which determines their residence time in the river (Fig. 3). The $16 \%$ decline per century in spring-summer flow suggests that less habitat may be available for salmon and other fish, as salmon fry emerge from their gravels in early spring, begin rearing, then migrate to the ocean. Possible impacts may include earlier (than historical norms) out-migration to the ocean for spring Chinook, changed timing of available freshwater and/or marine food sources, reduced summer flow, and longer returning migration times, impacting fall Chinook, steelhead, and coho the most, as they migrate during summer. Summer flows are expected to decline further. Trying to assess shifts in flow timing and salmon migration is problematic. For outmigrating juvenile sockeye (FPC 2012) during 1985-2009 (longest period available) at Rock Island Dam the CT for fish increased 5-days per decade while the CT for the Okanogan River (where $85 \%$ of the Columbia sockeye originate) decreased 2.5-days per decade. Migrating fish are impacted by flow, temperature, and turbidity, so confounding factors makes it difficult to assess specific impacts.

The increase of the 100-year October/November/December floods suggests that some major rain and rain-on-snow events could give duel positive and negative outcomes. A positive aspect is that mountain floods can be the catalyst for many hydrologic and physical processes that can enhance watershed ecosystem health such as cleaning silt out of spawning gravels and move nutrients downstream, which would benefit salmon (Swanson et al. 1998). A negative outcome is that very high runoff can scour the streambed and disrupt or destroy 
redds (i.e., egg nests), which fall Chinook, coho, and steelhead construct in September and October. Their eggs are most susceptible to strong increases in autumn flood risk.

Summer flows are also a concern. The 7Q10 analysis suggests a mixed-picture. The basins near the east-slope Washington Cascades and north Idaho had the highest negative change (i.e., lower flows), which is consistent with future trends noted in Elsner et al. (2009). The basins of northeast Oregon and central Idaho had an increase in summer flow. Lower summer flows decrease the amount of spawning habitat, can produce higher water temperatures, and reduce dilution of pollutants. Higher water temperatures have negative impacts on returning adult salmon reproduction, physiological response (e.g., heat shock, stress, disease resistance, bioenergetics and feeding), and pre-spawning mortality (McCullough et al. 2009). Pelto (2011) noted a substantial increase in the number of very low flow days in the glacier/snowmelt dominated Skykomish River Basin. Many Washington Cascade basins are fed by summer glacial melt, which is in decline due to warming temperatures (Grah and Beaulieu 2013).

CIG (2009) used the IPCC A1B and B emissions scenarios to show that Washington snowmelt basins could become transient and transient basins could become rainfalldominant by 2020, 2040, and 2080. The CIG study also shows an increase in the 20-year winter flood events, especially for basins in the central and southern Washington Cascades and a $5 \%-40 \%$ reduction in the summer (7Q10) flows by 2080. Mantua et al. (2010) shows the sensitivity of Washington State salmon freshwater habitats to climate change impacts. Increase in AR storms (Dettinger 2011) could pose even further risk to salmon eggs during their vulnerable incubation time.

Battin et al. (2007) focused on the Snohomish River basin (western Washington Cascades, north of Seattle, transient hydrography), using the GFDL R30 A2 and HadCM3 A2 scenarios for 2025 and 2050. Their conclusions are similar to the CIG study. Battin et al. (2007) and Crozier et al. (2008) noted that salmon mortality will likely increase due to higher water temperatures, lower flow for salmon spawners, and higher winter peak flows which may disrupt salmon nests. Chinook stocks could decline $20 \%$ by 2050 (Battin et al. 2007).

The impact of future climate change on the Columbia Basin tribal lands, water resources, and cultural resources (such as native plants) will likely be profound. Some of these basins are near the transition point for snow and rain, $0{ }^{\circ} \mathrm{C}$, as illustrated by Graves (2009). Graves noted that basins located closer to the Pacific Ocean and at moderate elevation, such as the Deschutes Basin in central Oregon, are most vulnerable, and high elevation basins, such as the Salmon Basin in Idaho, are more likely to be less affected by climate change impacts than lower elevation basins. Graves produced future scenarios with a snowpack model, using the IPCC A2 and B1 data, for 1971-2000, 2010-39, 2040-69, and 2070-99 for select tribal basins: Oregon - Deschutes, John Day, Umatilla; Washington - Yakima, Klickitat; Idaho - Salmon, Clearwater. It appears that some of these basins would change from snowmelt dominant to transient during the 2040s to 2080s. Such a shift would mean earlier snowmelt, lower summer flow and warmer late spring and summer water temperatures for such basins. Water temperature work continues on vulnerable basins, such as the Grande Ronde in northeast Oregon (Graves 2012).

Since 1938, the development and regulation of the Columbia River Basin hydro-system has shifted the annual lower Columbia River peak flow to earlier in the season and has been substantially reduced, primarily for flood control protection. Hydropower operations have increased winter flows (with less water for spring-summer) and irrigation has reduced summer flows (Online Resource 11), increasing fish travel times during spring-summer, which may reduce in-river survival, and reducing critical habitat, both contributing to the 
loss of fish productivity (ISG 2000). The development of the hydro-system, combined with overharvest from over 100 years ago (Online Resource 12) and the destruction of river habitat are stressors that have forced a steep decline of salmon abundance (ISG 2000). The reduction in summer flows can enhance the problems due to climate change and higher winter flows can increase impacts from more frequent winter flood events due to climate change noted in the headwaters.

\section{Conclusions}

Results of five independent flow measures indicate trending evidence for climate change for many of the study basins, despite strong interannual hydro-climate variability. The greatest change occurs in the low elevation basins of northeast Oregon, north Washington Cascades, and north-central Idaho. The trends imply that juvenile salmon may be forced to outmigrate earlier with less tributary river water, returning adults may be challenged by lower and warmer summer flows, and more scouring winter streamflows threaten their redds. Continuation of these trends may have negative impacts on Columbia Basin anadromous fish, their freshwater habitats, and the tribal peoples dependent upon them for spiritual and cultural sustenance.

Due to observed and projected changes, CRITFC and its member tribes are working on mitigation/adaptation projects (Gephart 2009, CRITFC 2013d). The Nez Perce implemented a Carbon Sequestration Plan on the Nez Perce Forest (NAU 2013). They also developed a Clearwater River Adaptation Plan that uses a forestry-watershed-economics approach (NPT 2011). Umatilla staff are conducting a project analyzing plant distribution changes due to climate change, which would impact their First Foods. Yakama staff are collaborating with USGS on a project to interview elders on climate change impacts. Warm Springs staff are negotiating with John Day River landowners to form conservation easements to reconnect the river to its tributaries and floodplains. Reconnections are an important climate change strategy to mitigate for increases in summer stream temperature, higher flows in winter, and lower flows during summer. Finally, there are legal and policy tools that tribes can consider when planning climate change strategies (UC-NRLC 2007).

Acknowledgments This work was partially supported by a 2009 EPA Indian Environmental General Assistance Program Grant (\#GA97020802-02) and a 2009 NOAA-PCSRF Watershed-Climate Change Grant awarded to CRITFC. Thank You to David Graves for the PRISM data and making the maps for Fig. 1, S1, S5, S10, S14, S15, S16, S20, S24; internal review by CRITFC's Bob Heinith, David Graves, Laura Gephart, and Brian McIlraith; Dr. David Garen, USDA-Natural Resources Conservation Service; Jim Ruff and John Fazio, Northwest Power and Conservation Council; Julie Maldonado and Benedict J. Colombi plus the reviewers. Your effort is appreciated and improved the paper.

Open Access This article is distributed under the terms of the Creative Commons Attribution License which permits any use, distribution, and reproduction in any medium, provided the original author(s) and the source are credited.

\section{References}

Aguado E, Cayan DR, Riddle LG, Roos M (1992) Climatic fluctuations and the timing of West Coast streamflow. J Clim 5(12):1468-1483

Barnett TP, Adam JC, Lettenmaier DP (2005) Potential impacts of a warming climate on water availability in snow-dominated regions. Nature 438:303-309 
Battin J, Wiley MW, Ruckelshaus MH, Palmer RN, Korb E, Bartz KK, Imaki H (2007) Projected impacts of climate change on salmon habitat restoration. Proc Natl Acad Sci 104(16):6720-6725

Beebee RA, Manga M (2004) Variation in the relationship between Snowmelt Runoff in Oregon and ENSO and PDO. Amer Water Resour Assoc 40(4):1011-1024. doi:10.1111/j.1752-1688.2004.tb01063.x

BPA-Bonneville Power Administration (2011) 2010 level modified streamflow: 1928-2008 diversion and return flow patterns, summation of depletion adjustments, 2010 level modified streamflow (plus Technical Appendix), DOE/BP-4352. Portland, Oregon

Cayan DR, Kammerdiener SA, Dettinger MD, Caprio JM, Peterson DH (2001) Changes in the onset of spring in the western United States. Bull Am Meteorol Soc 82(3):399-415

CIG-Climate Impacts Group (2009) Washington Climate Change Impacts Assessment, Ch. 6. University of Washington, Seattle. http://cses.washington.edu/cig/res/ia/waccia.shtml. Accessed 9 November 2012

CIG - Climate Impacts Group (2012) Climate Impacts on Pacific Northwest Water Resources. University of Washington, Seattle. http://cses.washington.edu/cig/pnwc/pnwwater.shtml. Accessed 9 November 2012

Cohen SJ, Miller KA, Hamlet AF, Avis W (2000) Climate change and resource management in the Columbia River Basin. Water Int 25(2):253-272

CRITFC - Columbia River Inter-Tribal Fish Commission (1995) Wy-Kan-Ush-Mi Wa-Kish-Wit (Spirit of the Salmon)_-Tribal Restoration Plan for Columbia River Salmon. Portland, Oregon. http://www.critfc.org/ fish-and-watersheds/fish-and-habitat-restoration/the-plan-wy-kan-ush-mi-wa-kish-wit. Accessed 9 November 2012

CRITFC - Columbia River Inter-Tribal Fish Commission (2013a) Salmon Culture. http://www.critfc.org/ salmon-culture/tribal-salmon-culture. Accessed 17 January 2013

CRITFC_Columbia River Inter-Tribal Fish Commission (2013b) Columbia River Salmon. http:// www.critfc.org/salmon-culture/columbia-river-salmon. Accessed 17 January 2013

CRITFC_Columbia River Inter-Tribal Fish Commission (2013c) Lamprey Restoration. http:// www.critfc.org/advocacy/lamprey-restoration. Accessed 17 January 2013

CRITFC_Columbia River Inter-Tribal Fish Commission (2013d) Salmon Restoration Projects. http:// www.critfc.org/fish-and-watersheds/fish-and-habitat-restoration/restoration-projects/search-results. Accessed 1 March 2013

Crozier LG, Zabel RW, Hamlet AF (2008) Predicting differential effects of climate change at the population level with life-cycle models of spring Chinook salmon. Glob Change Biol 14:236-249

Daly C, Neilson RP, Phillips DL (1994) A statistical-topographic model for mapping climatological precipitation over mountainous terrain. J Appl Meteorol 33:140-158

Dettinger MD (2011) Climate change, atmospheric rivers, and floods in California - a multimodel analysis of storm frequency and magnitude changes. Amer Water Resour Assoc 47(3):514-523. doi:10.1111/j.17521688.2011.00546.x

Dettinger MD, Cayan DR (1995) Large-scale atmospheric forcing of recent trends toward early snowmelt runoff in California. J Clim 8(3):606-623

Drummond B, Steele SJ (2013) Facing Climate Change-Plateau Tribes. http://www.facingclimatechange.org/ stories/plateau-tribes/ Accessed 2 March 2013

Elsner MM, Cuo L, Voisin N, Hamlet AF, Deems JS, Lettenmaier DP, Mickelson KEB, Lee SY (2009) Implications of 21 st century climate change for the hydrology of Washington State. In: Washington Climate Change Impacts Assessment: Evaluating Washington's future in a changing climate. http:// cses.washington.edu/db/pdf/wacciach3hydrology644.pdf. Accessed 17 January 2013

FPC_-Fish Passage Center (2012) Adult Salmon All Historic Counts; Smolt Data. http://www.fpc.org/ adultsalmon/adultqueries/Adult_Table_Species_AllHistoric.html. Accessed 9 November 2012

Gephart L (2009) Tribal salmon restoration and climate change in the Pacific Northwest. Ecol Restor 27(3):263266, http://fishery.critfc.org/FiSci/Gephart_ER27-3_pp263-266.pdf. Accessed 22 January 2013

Grah O, Beaulieu J (2013) The effect of climate change on glacier ablation and baseflow support in the Nooksack River basin and implications on Pacific salmon species protection and recovery. Clim Change doi:10.1007/s10584-013-0747-y

Graves D (2009) A GIS analysis of Climate Change and Snowpack on Columbia Basin Tribal Lands. Ecol Restor 27(3):256-257. doi:10.3368/er.27.3.256, http://fishery.critfc.org/FiSci/Graves_ER27-3_pp256257.pdf. Accessed 9 November 2012

Graves D (2012) A simulation of water temperature in the upper grande ronde basin with future climate change scenarios. CRITFC Tech. Rep. 12-09. http://fishery.critfc.org/FiSci/12_09report.aspx. Accessed 9 November 2012

Hamlet AF, Lettenmaier DP (2007) Effects of 20th century warming and climate variability on flood risk in the western U.S. Water Resour Res 43:W06427. doi:10.1029/2006WR005099 
Hamlet AF, Mote PW, Clark M, Lettenmaier DP (2005) Effects of temperature and precipitation variability on snowpack trends in the western U.S. J Clim 18(21):4545-4561

Helsel DR, Hirsch RM (1992) Statistical methods in water resources. Elsevier Science Publishing, New York. ISBN 0-444-88528-5

Hidalgo HG, Das T, Dettinger MD, Cayan DR, Pierce DW, Barnett TP, Bala G, Mirin A, Wood AW, Bonfils C, Santer BD, Nozawa T (2009) Detection and attribution of streamflow timing changes to climate change in the western United States. J Clim 22:3838-3855

ISAB - Independent Scientific Advisory Board (2007) Climate change impacts on Columbia River Basin Fish and Wildlife. Report 2007-2. Northwest Power and Conservation Council. http://www.nwcouncil.org/fw/ isab/isab2007-2. Accessed 27 March 2013

ISG Independent Scientific Group (2000) Return to the River-Restoration of Salmonid Fishes in the Columbia River Ecosystem. Report to the Northwest Power and Conservation Council. http:// www.nwcouncil.org/reports/2000/2000-12. Accessed 27 March 2013

Jager HI, Cardwell HE, Sale MJ, Bevelhimer MS, Coutant CC, van Winkle W (1997) Modeling the linkages between flow management and salmon recruitment in rivers. Ecol Modeling 103:171-191

Linsley RK Jr, Kohler MA, Paulhus JLH (1982) Hydrology for engineers, 3rd edn. McGraw-Hill, New York. ISBN 0-07-037956-4

Luzier CW et al (2011) Pacific lamprey assessment and template for conservations measures. US Fish and Wildlife Service, Portland

Mantua NJ, Hare SR, Zhang Y, Wallace JM, Francis RC (1997) A pacific interdecadal climate oscillation with impacts on salmon production. Bull Am Meteorol Soc 78(6):1069-1079

Mantua NJ, Tohver I, Hamlet AF (2008) Impacts of climate change on key aspects of freshwater salmon habitat in Washington State. Future Climate in the Pacific Northwest. University of Washington, Climate Impacts Group, Seattle

Mantua NJ, Tohver I, Hamlet AF (2010) Climate change impacts on streamflow extremes and summertime stream temperature and their possible consequences for freshwater salmon habitat in Washington State. Clim Change 102(1-2):187-223. doi:10.1007/s10584-010-9845-2

Maurer EP, Stewart IT, Bonfils C, Duffy PB, Cayan D (2007) Detection, attribution, and sensitivity of trends toward earlier streamflow in the Sierra Nevada. J Geophys Res-Atmos 112:D11124

McCullough DA et al (2009) Research in thermal biology: burning questions for coldwater stream fishes. Rev Fisheries Sci 17(1):90-115. doi:10.1080/10641260802590152

Meyer DF, Dodge JE (1988) Post-eruption changes in channel geometry of streams in the Toutle River Drainage Basin, 1983-85, Mount St. Helens, Washington. U.S. Geological Survey Open-File Rep. 87549

Miles EL, Snover AK, Hamlet AF, Callahan BM, Fluharty DL (2000) Pacific Northwest regional assessment: the impacts of climate variability and climate change on the water resources of the Columbia River Basin. Amer Water Resour Assoc 36(2):399-420. doi:10.1111/j.1752-1688.2000.tb04277.x

Mote P (2003) Trends in snow water equivalent in the Pacific Northwest and their climate causes. Geophys Res Lett 30(12):1601. doi:10.1029/2003GL017258

Mote P, Hamlet AF, Salathé E (2008) Has spring snowpack declined in the Washington Cascades? Hydrol Earth Syst Sci 12:193-206. doi:10.5194/hess-12-193-2008

Mote P, Salathé E (2010) Future climate in the Pacific Northwest. Clim Change 102(1-2):29-50

NAU-Northern Arizona University Institute for Tribal Environmental Professionals (2013) Nez Perce Tribe: Carbon Sequestration Program. http://www4.nau.edu/tribalclimatechange/tribes/northwest_nezperce.asp. Accessed 22 January 2013

NPCC - Northwest Power and Conservation Council (2013) Pocket Guide-Fast Facts About the Columbia River Basin. http://www.nwcouncil.org/reports/brochures/pocket-guide. Accessed 27 March 2013

NPT-Nez Perce Tribe Water Resources Division (2011) Clearwater River Sub-basin Climate Change Adaptation Plan. http://fishery.critfc.org/FiSci/data/CCAP_final.pdf Accessed 1 March 2013

Onoz B, Bayazit M (2003) The power of statistical tests for trend detection. Turkish J Engr Envir Sci 27(4):247-251

Pelto MS (2008) Impact of climate change on North Cascade Alpine Glaciers, and Alpine Runoff. Northwest Sci 82(1):65-75

Pelto MS (2011) Skykomish River, Washington: impact of ongoing glacier retreat on streamflow. Hydrol Process 25:3356-3363. doi:10.1002/hyp.8218

PRISM-Parameter-evaluation Regressions on Independent Slopes Model (2012) Oregon State University, Corvallis, Oregon. http://www.prism.oregonstate.edu. Accessed 9 November 2012

Quinn TP (2005) The behavior and ecology of pacific salmon and trout. University of Washington Press, Seattle. ISBN 0295984570 
Swanson FJ, Johnson SL, Gregory SV, Steven A (1998) Flood disturbance in a forested mountain landscape. Biosci 48(9):681-689, http://andrewsforest.oregonstate.edu/pubs/pdf/pub2430.pdf Accessed 1 March 2013

Slack JR, Landwehr JM (1992) Hydro-Climate Data Network (HCDN): A U.S. Geological Survey, Streamflow Data Set for the United States for the Study of Climate Variations, 1874-1988. U.S. Geological Survey Open-File Rep. 92-129. http://pubs.usgs.gov/of/1992/ofr92-129/

Stewart IT, Cayan DR, Dettinger MD (2005) Changes toward earlier streamflow timing across western North America. J Clim 18(8):1136-1155. doi:10.1175/JCLI3321.1

UC-NRLW-University of Colorado Natural Resources Law Center (2007) Native Communities and Climate Change: Legal and Policy Approaches to Protect Tribal Legal Rights

USDA-NASS - United States Department of Agriculture National Agricultural Statistics Service (1997) 1997 Census Publications, Volume 1, Chapter 1: State Level Data

USGS-United States Geological Survey (1995) National Water-Use Information Program

USGS-United States Geological Survey (2012). Real-time water data for the nation. http://waterdata.usgs.gov/ usa/nwis/rt. Accessed 9 November 2012

Weaver T (1997) Litigation and Negotiation: the History of Salmon in the Columbia River Basin. Ecol Law Quarterly 24(44):677-697 